\title{
Effect of Variety Seeking and Electronic Word of Mouth on Brand Switching (Study on Millennial Generation as Modern Coffee Shop Consumers in Surabaya)
}

\author{
Marisa Arnindita Palma; Sri Setyo Iriani; Harti \\ Program Pasca Sarjana Manajemen, Universitas Negeri Surabaya, Indonesia
}

http://dx.doi.org/10.18415/ijmmu.v8i8.2976

\begin{abstract}
The purpose of this study is to find out the Effect of Finding Variations and Communicationby OnlineWord of Mouthtoward Brand Switching (Study on Coffee Shop Consumers in Surabaya). This type of research is conclusive research. Research with problem solving research studies using the number of respondents as many as 200. As for obtaining data from 200 respondents, researchers added an error sampling of $5 \%$ so that the number of respondents as many as 210 . Sampling techniques used in this study are non probability sampling, with judgemental sampling method and snowball sampling. The results of this study showed that the search for variations positively influenced the Switching of Consumer Brands of Modern Coffee Shops in Surabaya e-WOM has a positive effect on the Switching of Consumer Brands of Modern Coffee Shops in Surabaya.
\end{abstract}

Keywords: Variety Seeking; Consumer Brand Switching; e-WOM; Modern Coffee Shop

\section{Introduction}

Coffee shop, nowadays we often hear the term coffee shop. The development of coffee shops in Indonesia itself has also reached 2950 shops in August 2019, which means a threefold increase compared to 2016 which only had 1000 shops with a revenue value of 4.8 trillion (Toffin, 2019).(Dahwilani, 2019)also explained that the results of research conducted by Toffin is that coffee consumption in Indonesia is currently growing $13.9 \%$ per year where this figure has exceeded the average coffee consumption in the world by $8 \%$. This is due to a shift in the culture of drinking coffee. According to experts in the journal (Solikatun et al, 2015) that in a cup of coffee there are psychotropic substances, the most we know is caffeine which can stimulate two stimulant hormones. These hormones are cortisol and adrenaline which have a sleep-relieving effect and are able to increase mental awareness, focus, thought, and response.

Research conducted by(Susanto \& Widyawati, 2016)that the search for variety can significantly affect one's brand switching. Other research conducted by(Thawil, 2014)that the search for variation has a significant effect on brand switching. The results of research conducted by(Faustine, 2015)also confirmed that the search for variations has a significant effect on brand switching. However, in a study conducted by(Pasaribu \& Sugiarto, 2011)Variety Seeking has no effect on brand switching. The indicators used in the study were Boredom, Curiosity, and Desire to try new products. Search for variation in research(Cheng et 
al., 2016)included in one of the factors that can affect someone in switching brands. (Safitri \& Septrizola, 2019)explained that in his research the Variety Seeking variable has a significant effect on brand switching behavior. The research conducted on Instant Noodle consumers in Manado also resulted that the search for variations can affect brand switching. Indicators used in research of(Safitri \& Septrizola, 2019)are brand saturation, curiosity about other brands, and desire to try other brands.

However, in a study conducted by (Suharseno et al., 2013)Variation seeking behavior is only a moderating variable in consumer dissatisfaction with switching behavior and has no effect on brand switching itself. The study used indicators of consuming experience, frequency of purchase, and a sequence of brand choices. The indicators used in this study will use the indicators carried out by(Safitri \& Septrizola, 2019)because the research object used comes from the Food and Beverage industry. The occurrence of a gap between these studies will make the basis for researchers to take this variable.

Another factor that can influence brand switching apart from Variety Seeking is Online Word of Mouth. According to Chatterjee in the research of Jallvand and Samiei (2012), a negative or positive information using electronic media, especially social media is one type of promotion method in the form of word-of-mouth communication that can play an important role in determining consumer attitudes and behavior. Along with the development of information technology the concept of Word of Mouth has shifted to Electronic Word of Mouth (e-WOM). Nowadays, e-WOM or in Indonesian referred to as Online Word of Mouth Communication is one of the most efficient methods of influencing one's needs so that it is very easy for consumers to switch brands.

The research is supported by research conducted by(Pirdaus et al., 2020)which revealed that electronic word of mouth (e-WOM) has a significant effect on brand switching. This happens because eWOM from the object of research is very good so that consumers understand more about product knowledge so that it can cause the desire to switch brands. The indicators in this study are intensity, content, positive opinion, and negative opinion. While other research conducted by(Maretama et al., 2018)that e-WOM does not have a significant effect on brand switching but can affect brand image so that it can cause brand switching. The indicators used in this study are e-WOM quality, e-WOM quantity, and Sender's Expertise. In research conducted by(Gunawan et al., 2016)e-WOM has an indirect effect on brand switching with brand image as an intervening variable. The indicators used in this research are e-WOM intensity, Positive Valence WOM, Negative Valence WOM, and e-WOM Content.

Research conducted by(Pelupessy et al., 2017) which was done on Samsung smartphone users had the result that e-WOM had an effect on brand switching on these users. (Zhang et al., 2015)in his research proves that negative e-WOM can affect brand switching. Negative e-WOM in this study used the indicators of Negative e-WOM Number, Negative e-WOM Reliability, and Negative e-WOM Retransmission Will. The indicators that will be used in this study refer to the research conducted by (Pirdaus et al., 2020)because the research includes all components that are in accordance with the object in this study where the object of this research is Instagram social media. This gap between studies makes this variable is good for further research.

One of the most popular social media for millennials is Instagram. As explained by Bohang (2018) in Kompas.com that Monthly Active Users (MAU) Instagram reached 1 billion in June 2018. The growth was the most significant compared to Facebook and Snapchat, which reached 5 percent year on year according to in Figure 1 below: 


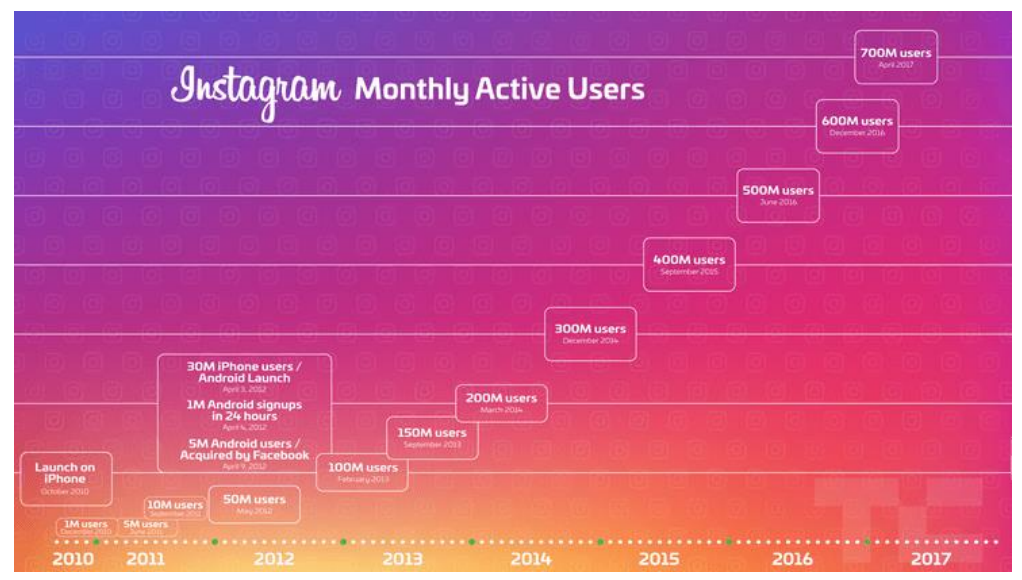

Figure 1. Growth of Monthly Active Users Instagram

Source: Kompas.com (2018)

Instagram social media is also very fast in its development compared to other social media applications. This can happen because Instagram is very fast in developing its features. Where the development of the features of social media is more interesting than other social media.In addition, the unique characteristics of generation $\mathrm{Y}$ or referred to as the millennial generation have controlled $40 \%$ so that this generation cannot be separated from the internet. This phenomenon is then used by business actors to promote their products. Including business people in the Modern Coffee Shop.

According to Ario Fajar in Dwinanda (2019) Coffee shops that are growing today can be classified into seven types of coffee shops. First, the American Coffee Shop where this outlet is a favorite for coffee lovers, which are generally located in shopping centers. Examples of American Coffee Shops are Starbucks and Coffee Bean. Second, the Italian Coffee Shop which not only provides coffee, but combines two different concepts between a Bar and a Coffee Shop, an example is Seagafredo. The third is the type of local coffee shop which from Indonesians, for example: Excelso.The fourth type of coffee shop is Coffee to Go where this type of shop is not a place to enjoy coffee and usually the number of seats is limited, examples of this type of coffee shop are Kopi Kenangan and Janji Jiwa. Fifth is Specialty Coffee, this type of shop usually serves special coffee by featuring a roaster that can roast the coffee beans themselves to produce delicious coffee. The sixth is the type of coffee shop that does not have many outlets, usually this shop only has one because it favors an Instagramable interior design, examples of this coffee shop are rvang, Blackbarn Coffee, and TitikKoma. The seventh type of coffee shop is a bakery where the bakery sells various types of cakes and also provides coffee as a complementary menu to the main dish, for example The Harvest.

Data obtained from IDN Times stated that $44.3 \%$ of Java's coffee milk lovers are from East Java, along with data obtained: 


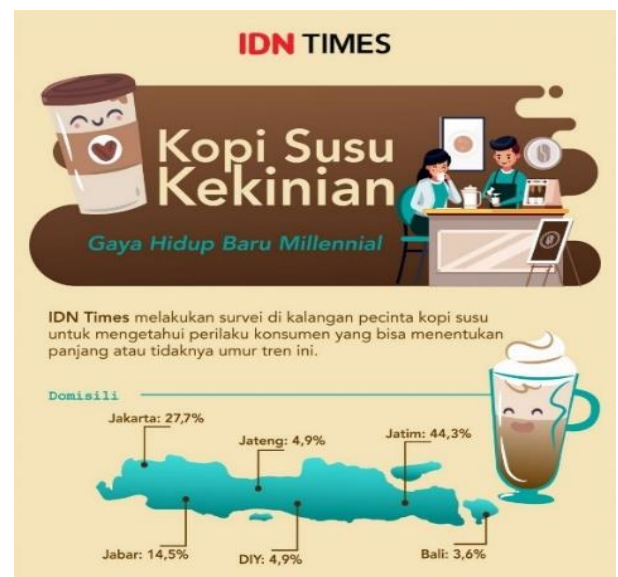

Figure2 Data on The Number of Contemporary Coffee Milk Lovers

Source: IDN Times (2019)

The data shows that almost half of the entire population of the island of Java who likes contemporary coffee comes from East Java. The development of coffee shops in East Java can be found in big cities of East Java, especially the city of Surabaya. The growth of this coffee shop was also revealed by the Chairman of ApkrindoJatimTjahjonoHaryono that they have noted that there are around 2000 culinary businesses in the city of Surabaya and about $18 \%$ are coffee-based cafes which continue to grow due to the influence of changes in people's habits today. IDN Times also mentioned that there are several coffee shops that are favorites for the people of Surabaya, here is a list of these coffee shops.

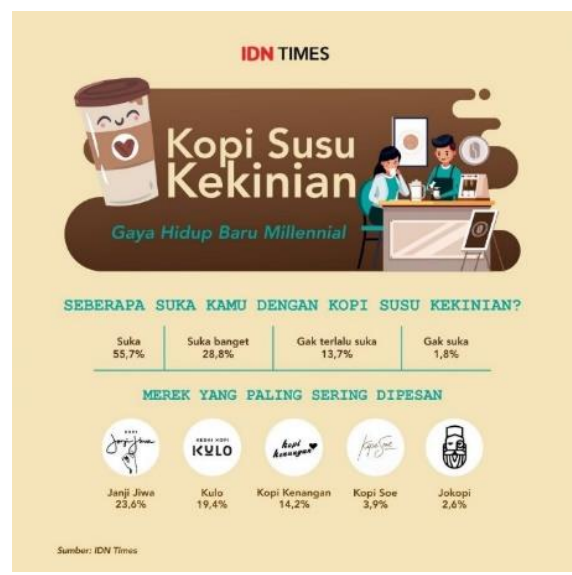

Figure 3Frequently ordered coffee shop brands

Source: IDN Times (2019)

The data above states that there are 5 coffee shops in Surabaya that are often ordered, namely:Janji Jiwa, Kedai Kopi Kulo, Kopi Kenangan, Kopi Soe, and Jokopi. The five brands have provided coffee-togo services to make it easier for consumers. So that this research will be conducted on consumers who have ordered one of the five brands. This research was also conducted to determine how marketers' strategies, especially in the coffee shop industry, can develop and sustain this business by utilizing individual differences and situational factors that can use Instagram social media. Based on the background explanation above, this study aims to determine the effect of searching for variations and online word-ofmouth communication on brand switching (Study on Coffee Shop Consumers in Surabaya).

\section{Literature Review}




\section{Consumer Behavior}

Consumer behavior according to Schiffman and Kanuk (2010:7) defines as consumer behavior when searching, buying, using, then evaluating, and spending a product and service that is expected to meet the needs.

\section{Brand Switching}

Research conducted by(Pirdaus et al., 2020)states that brand switching is a time when a customer switches to another brand and leaves the old brand to consume other brand's products. From the definition of the experts above, it can be concluded that brand switching is when consumers start to leave a brand and make purchases at other brands for some reason. Indicators that are in accordance with the object of research and will be used in this study use indicators from the research(Gunawan et al., 2016; Maretama et al., 2018)

1) Internal Environment

2) External Environment

3) Emotional Response

4) Rational Response

\section{Variety Seeking}

According to Susanto research (2016) concludes that this brand switching often occurs because of the success of marketers in offering a product to get consumers' attention. It can be concluded that the search for variations is a person's behavior to look for other variations of the previous product because they want to try new experiences.

Measurement indicator for Variety Seeking variable by(Susanto \& Widyawati, 2016) as follows:

1) Boredom, consumers who consume a product more often tend to get bored more quickly, so consumers will look for other variations.

2) Curiosity, the curiosity of consumers on a product is also due to promotional assistance carried out by business actors.

3) The desire to try new products, the emergence of this new product is also one of the attractions of consumers to try other variations.

\section{Electronic Word of Mouth (e-WOM)}

(Pirdaus et al., 2020)Electronic word of mouth can be called the most effective information media to market a product through one's experience where the experience is conveyed to other people who have their own trust values. According to Hennig-Thurau et al. in(Gunawan et al., 2016)defines e-WOM as a positive or negative statement made by a customer about a product that has been consumed and the statement is available on the Internet. Variable indicators in research(Pasaribu \& Sugiarto, 2011) and (Maretama et al., 2018) are:

1) Quality of e-WOM

The quality of e-WOM refers to the persuasive power of comments embedded in informational messages. Consumer purchasing decisions can be based on several criteria, namely being able to meet the needs and the perception of information received by consumers. 


\section{2) Quantity of e-WOM}

The e-WOM quantity refers to the total number of comments posted. The popularity of the product is determined by the number of online comments because it is considered to represent the product's performance. In other words, consumers will perceive that more reviews will represent the popularity of a product.

\section{3) Experience of the informant}

The experience in question is how consumers who have consumed submit their reviews. The results of consumer reviews that attract other consumers can be taken into consideration in making purchases.

\section{Framework of Thinking}

The rapid development of coffee shops in Indonesia is an interesting thing to research. This development has tripled in the last five years. This happens because all Coffee Shops almost sell the same product with almost the same concept so that consumers are offered by a lot of variety in the market. As we know the habit of drinking coffee was only for some people because coffee itself contains several chemicals that can help someone to do work. However, the current phenomenon that occurs is that the habit of drinking coffee is very popular with the Millennial Generation. According to the characteristics of this generation, they are a generation that is easily influenced by reference groups over the internet and likes new things.

From this phenomenon, it can be concluded that the search for variations and electronic word of mouth can influence brand switching

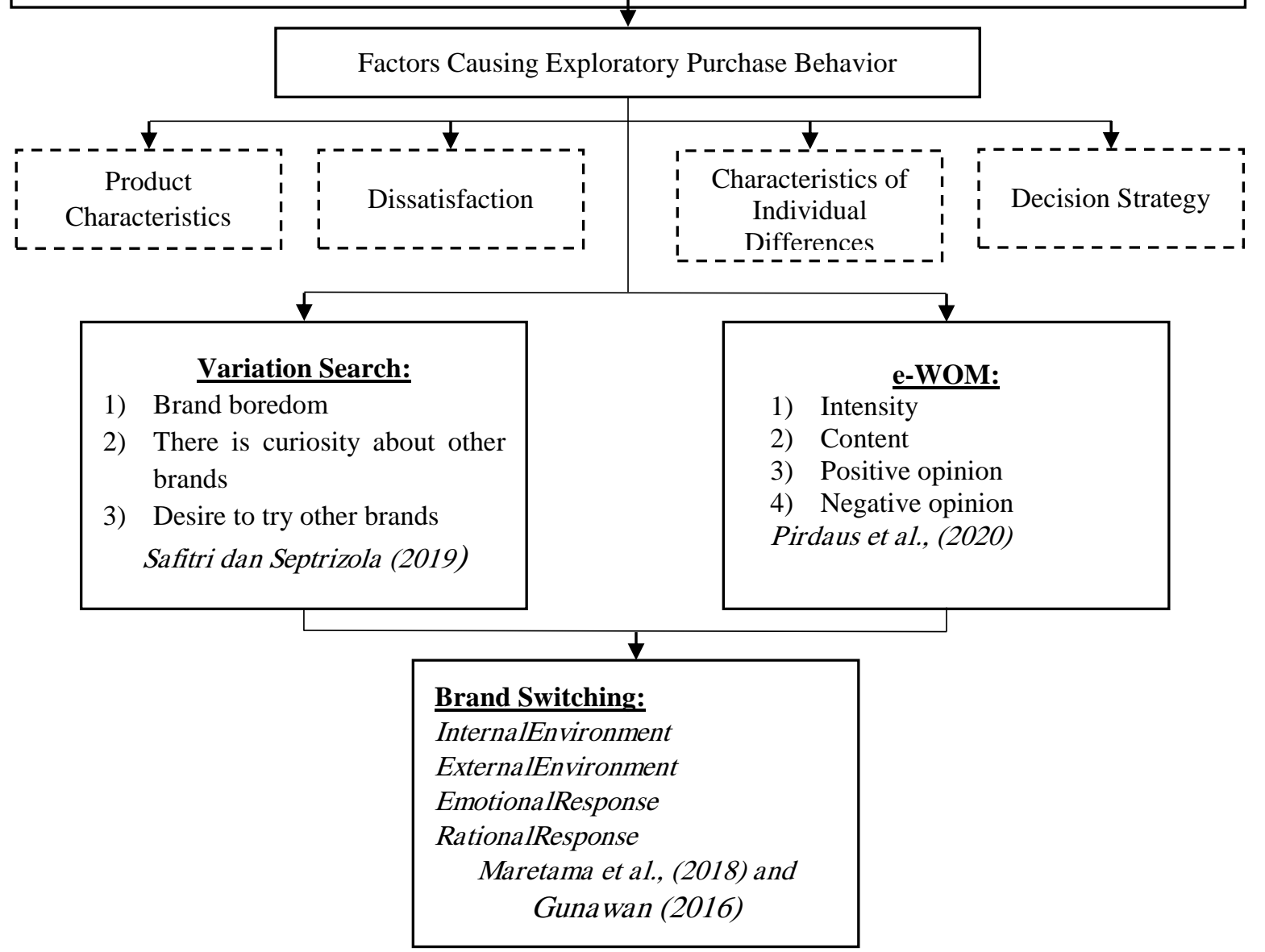

Figure 4: Framework of thinking, Source: Hoyer and Ridgway (1984), data processed by researchers 
From the framework of thinking that has been described previously, the following hypotheses can be proposed:

H1 : There is an effect of Variety Seeking on brand switching.

H2 : There is an effect of electronic word of mouth on brand switching.

\section{Research Methods}

This type of research is a conclusive research. Conclusive research according to Maholtra (2009: 90 ) is a study that aims to test a hypothesis and look for relationships between variables. This study has a large number of samples to represent the population. Data analysis in this study is quantitative.

This research design is designed to make it easier and to find out whether there is an effect of Variety Seeking and e-WOM on brand switching on Modern Coffee Shop consumers in Surabaya. The independent variables of this study are Variety Seeking $\left(\mathrm{X}_{1}\right)$ and e-WOM $\left(\mathrm{X}_{2}\right)$, while the dependent variable of this research is brand switching (Y). Research with problem solving research studies uses 200 respondents. Meanwhile, to obtain data for 200 respondents, the researcher adds a sampling error rate of $5 \%$ so that the number of respondents is 210 . The addition of this sampling error aims to anticipate damaged questionnaires.

The sampling technique used in this study is non-probability sampling, with judgmental sampling and snowball sampling methods. Data collection techniques in this study used several types, while the types of data used in this study included the primary data sources in this study obtained from the results of distributing questionnaires to all samples. Secondary data in this study comes from reference books, journals or previous research, data in the field relevant to the research. This study uses Multiple Linear Analysis Techniques. Before carrying out the analysis technique, the researcher first conducted several classical assumption tests.

\section{Research Result}

\section{Research Description}

The results of the description of the respondent's profile were taken based on the demographics of all respondents seen from gender, age, income, occupation, and buying experience at a coffee shop in accordance with the questionnaire that had been divided by the researcher. The results of the crosstabs of respondents' characteristics based on demographics can be seen in the table below:

Table 1. Results Characteristics of respondents based on Demographics

\begin{tabular}{|c|c|c|c|c|}
\hline No. & \multicolumn{2}{|c|}{ Characteristics of respondents } & Amount & Percentage (\%) \\
\hline \multirow{2}{*}{1} & \multirow{2}{*}{ Gender } & Male & 127 & $60 \%$ \\
\hline & & Female & 83 & $40 \%$ \\
\hline \multirow{4}{*}{2} & \multirow{4}{*}{ Age } & $20-25$ years old & 64 & $30 \%$ \\
\hline & & $26-30$ years old & 85 & $40 \%$ \\
\hline & & $31-35$ years old & 50 & $24 \%$ \\
\hline & & 36 - 40 years old & 11 & $5 \%$ \\
\hline
\end{tabular}




\begin{tabular}{|c|c|c|c|c|}
\hline No. & \multicolumn{2}{|c|}{ Characteristics of respondents } & Amount & Percentage (\%) \\
\hline \multirow{6}{*}{3} & \multirow{6}{*}{ Profession } & Student & 46 & $22 \%$ \\
\hline & & Freelancer & 41 & $20 \%$ \\
\hline & & Private employees & 77 & $37 \%$ \\
\hline & & Civil Servant & 26 & $12 \%$ \\
\hline & & Entrepreneur & 14 & $7 \%$ \\
\hline & & others & 6 & $3 \%$ \\
\hline \multirow{4}{*}{4} & \multirow{4}{*}{ Income } & $<1.500 .000$ & 25 & $12 \%$ \\
\hline & & $1.500 .000-3.000 .000$ & 38 & $18 \%$ \\
\hline & & $3.000 .000-4.500 .000$ & 80 & $38 \%$ \\
\hline & & $>4.500 .000$ & 68 & $32 \%$ \\
\hline \multirow{5}{*}{5} & \multirow{5}{*}{ Coffee shop that ever visited } & Janji Jiwa & 197 & $94 \%$ \\
\hline & & Kopi Kenangan & 185 & $88 \%$ \\
\hline & & Kedai Kopi Kulo & 139 & $66 \%$ \\
\hline & & Kopi Soe & 177 & $84 \%$ \\
\hline & & Jokopi & 116 & $55 \%$ \\
\hline
\end{tabular}

Source: data processed by researchers (2021)

Based on the results of the cross-tabulation calculations that have been processed by the researcher, it can be described that the characteristics of the respondents in this study were the majority of respondents in this study were male with 127 male respondents and most of them were aged 26-30 years who were private employees with income 3,000,000 -4,500,000. The most frequent coffee shop buying experience is at Janji Jiwa.

\section{Description of Research Variables}

Description of respondents' answers to the research variables will be explained in each research variable. Description of respondents' answers is done by calculating the average value of each variable. The formula for calculating the average value of respondents' answers is as follows:

$$
\begin{aligned}
\text { Class interval } & =\frac{\text { the highest score }- \text { the lowest score }}{\text { Total class }} \\
& =\frac{5-1}{5}=0,8
\end{aligned}
$$

After obtaining the results of the class interval of 0.8 then it can be determined the results of the criteria for the average respondents' answers as follows:

Table 2. Respondent's Answer Category Interval

\begin{tabular}{|c|l|}
\hline \multicolumn{1}{|c|}{ Interval } & \multicolumn{1}{c|}{ Category } \\
\hline $4,20<\mathrm{a}=<5,00$ & Strongly Agree \\
\hline $3,40<\mathrm{a}=<4,20$ & Agree \\
\hline $2,60<\mathrm{a}=<3,40$ & Quite Agree \\
\hline $1,80<\mathrm{a}=<2,60$ & Disagree \\
\hline $1,00<\mathrm{a}=<1,80$ & Strongly Disagree \\
\hline
\end{tabular}


The description of respondents' answers describes the average answers of respondents to statement items on indicators in each variable. The results of the analysis of respondents' answers to each statement item are as follows:

Table 3. Descriptive Statistical Results of Research Variables

\begin{tabular}{|c|c|c|c|c|}
\hline No & Variable & Statement Items & Mean & Desc. \\
\hline \multirow{3}{*}{1} & \multirow{3}{*}{ Variety Seeking } & Brand Saturation & 3.55 & Agree \\
\hline & & There is curiosity about other brands & 3.64 & Agree \\
\hline & & Desire to try other brands & 3.68 & Agree \\
\hline \multirow{8}{*}{2} & \multirow{8}{*}{ e-WOM } & Product Information Search via Instagram & 3.69 & Agree \\
\hline & & Interaction on information submitted via Instagram & 3.27 & Quite Agree \\
\hline & & $\begin{array}{l}\text { The number of reviews of the Modern Coffee Shop } \\
\text { in Surabaya }\end{array}$ & 3.44 & Agree \\
\hline & & Review Result Details & 3.88 & Agree \\
\hline & & Reviews include prices & 3.86 & Agree \\
\hline & & Positive Comments from previous Consumers & 3.75 & Agree \\
\hline & & Consumers previously recommended the product & 3.41 & Agree \\
\hline & & Negative Comments from previous Consumers & 3.86 & Agree \\
\hline \multirow{7}{*}{3} & \multirow{7}{*}{ Variety Seeking } & Product Information Search via Instagram & 3.69 & Agree \\
\hline & & Interaction on information submitted via Instagram & 3.27 & Quite Agree \\
\hline & & $\begin{array}{l}\text { The number of reviews of the Modern Coffee Shop } \\
\text { in Surabaya }\end{array}$ & 3.44 & Agree \\
\hline & & Reviews include prices & 3.86 & Agree \\
\hline & & Positive Comments from previous Consumers & 3.75 & Agree \\
\hline & & Consumers previously recommended the product & 3.41 & Agree \\
\hline & & Negative Comments from previous Consumers & 3.86 & Agree \\
\hline
\end{tabular}

Source: data processed by researchers (2021)

Based on the results of respondents' answers in the table above, it shows that the Variety Seeking variable on the indicator of the desire to try other brands has an average value of 3.68 and is included in the Agree category. This shows that respondents have a desire to try other brands from one of the Modern Coffee Shops in Surabaya.In the e-WOM variable, the indicator with the greatest value is the indicator on Details of Review Results which has a value of 3.88 and is included in the Agree category. This shows that consumers have previously provided detailed review results on modern coffee shop products in Surabaya. Details of the results of the review in the form of a description of the taste, aroma, and the appearance of the product. Meanwhile, the Brand Switching variable which has the highest indicator value is the indicator of the unavailability of the desired product which has a value of 3.68 and is included in the Agree category. This shows that respondents have experienced an unavailability of the desired product when ordering a menu from the Modern Coffee Shop.

\section{Discussion}

\section{Variety Seeking Affects Brand Switching}

Based on the results of the research regression test above, the results obtained that the Variety Seeking variable $\left(\mathrm{X}_{1}\right)$ has a positive effect on Brand Switching $(\mathrm{Y})$. This means that the more variations in the market, which causes the Consumers' Search for Variations to be higher, so that it can increase the switching of modern coffee shop consumer brands. The results of this study are in accordance with the 
theory stated by Hoyer and Ridgway (1984) In the theoretical model of Purchasing Exploration Behavior, that Purchasing Exploration by consumers is influenced by several factors, one of the influencing factors is the characteristics of individual differences. The existence of these individual differences then encourages the need to look for variations in each different consumer according to the personality characteristics of each individual. The existence of this Variety Seeking behavior then also encourages the exploration of purchases that can be in the form of brand switching and innovation. The results of this study support the research conducted by Susanto (2016), Khasanah (2013), Cheng et al. (2016), and Suharseno (2013) that the search for variation has a positive effect on brand switching. Research conducted by Cheng et al. (2016) explained that with increasing age, consumers already have a stable feeling so that the desire to seek variety decreases. However, in this study where most of the respondents are millennials, they tend to have a sense of wanting to try new things.Research of Faustine(2015), Astuti\&Santoso(2020), and Sang et al.(2018) shows that the more variety of products on the market will increase one's brand switching Sang et al., 2018also explained that to attract new consumers, marketers can motivate non-customers to make a brand switch. The non-customer motivation referred to in the study is to make improvements to the store atmosphere or by adding brand attributes.

This study uses 3 indicators to measure the Variety Seeking variable, namely Brand Saturation, curiosity about other brands, and the desire to try other brands. The Variety Seeking indicator that has the highest score is "Desire to try other brands" with an average value of 3.68. This shows that consumers are not dissatisfied with the previous product, they just want something new that attracts attention. This is because the promotional strategy carried out by many marketers involves social media where marketers will design their products as attractively as possible so that many consumers are interested. Not only product design but attractive offers so that consumers are quick to switch brands. The offer can be in the form of a purchase promo that benefits consumers. In addition, consumers will be more interested if this coffee shop can create new products that are different from other coffee shops. So that almost all Modern Coffee Shops in Surabaya are competing to create new menu variations. This is why there are so many variations in the market that encourage consumers to try these products and the rate of switching from one brand to another is very high.

Next is curiosity with an average value of 3.64 , some consumers search for variations because they are curious about other brands. Then the indicator of brand saturation with an average value of 3.55 or in other words this indicator has the lowest value when used to measure the Variety Seeking variable. This is in accordance with the characteristics of the respondents in this study where the millennial generation likes new things. This behavior can indicate that consumers in this study are looking for variations not because they are saturated with other brands but consumers just want to try new things.

The management strategy that can be built by business actors is to create new innovations that can attract consumers. Consumers, especially in this study, are the millennial generation, so business actors must be able to attract the attention of this generation. this generation likes new things but this generation is also easily bored with new products so it can be strived that business actors can better understand their desires. The more product variants on the market, the higher the brand switching behavior. To keep this generation of consumers loyal is to provide good quality and satisfactory service. This generation, known as the consumptive generation, no longer considers the price but pays more attention to how the product can fulfill its satisfaction. To attract the attention of consumers, it is also not only creating new innovations but also creating interesting promotional content.

\section{e-WOM has an Effect on Brand Switching}

Another most unique characteristic of the millennial generation is that they believe in reference groups, so their behavior in making decisions can also be influenced by reference groups, including the 
information they get from Instagram social media. Social media has become one of the effective media in connecting information between consumers by utilizing its features. Where the features of the application can be seen by the public. So, it is very easy for this generation to find the desired information. This term can be referred to as electronic word of mouth (e-WOM). The higher the influence of e-WOM is able to increase the brand switching of a consumer. This study also proves that e-WOM has a positive effect on brand switching.

This study also supports research conducted by Pasaribu (2011) and Gunawan (2016) where the results of these studies state that e-WOM has a positive effect on brand switching. The difference between WOM and e-WOM itself is in the level of effectiveness of faster information dissemination using e-WOM. This is because the e-WOM method itself can be done anywhere and anytime involving social media. Social media has become very effective as a medium for disseminating information because all social media users will search for information about a product on social media. The theory by Hoyer and Ridgway (1984) which explains the Exploratory Behavior of Consumer Purchases, one of which is influenced by situational factors, where one of the situational factors is the influence of others. This shows that the results of this study support the theory of Hoyer and Ridgway.

Research conducted by Nadarajan (2017) that the power of information contained in e-WOM can affect consumer trust. The more messages conveyed through social media it will be able to influence the desire to switch brands. On the other hand, another study conducted byZhang et al., (2015)revealed that eWOM is a strategy that can be profitable or detrimental, good or bad the consumer experience will be quickly conveyed to all social media. Hence, marketers must pay attention to every interaction made by consumers on social media so as not to make a loss for the company.

The indicator chosen by many respondents on the e-WOM variable in this study is "Detailed Review Results", this means that social media users who become consumers of modern coffee shops when looking for information prioritize product review details, such as taste, smell, atmosphere. , up to the price given by Modern Coffee Shop in Surabaya.The main consumers in this research object are the millennial generation who prefer the results of the review in the reference group. The reference group in question is the closest relatives and other consumers who have tried. They will trust referral groups more than marketers' promotional language. So that today's marketers can take advantage of the behavior of these consumers by giving a gift if they give a good review on the Modern Coffee Shop in Surabaya.While the lowest average of this variable indicator is Interaction on information submitted through Instagram with an average value of 3.27 , this shows that when consumers get information, they tend not to do any interaction such as commenting, liking, and even sharing. This happens because the dominance of the respondents in this study are consumers aged 26-30 years, where at that age the respondents are in the productive age category who only surf on social media to see what they are looking for without doing any interaction with the content created by the users. marketer.

The most effective management strategy in marketing products for this generation is to involve social media. One of the social media with the highest number of users is Instagram. The number of Instagram users is due to the easy use of the media and the many features that other social media do not have. Not only that, the speed of information to be received by all users is also one of the advantages of Instagram, besides that this social media can also be accessed anywhere and anytime. This can be an opportunity for marketers to provide information about their new products. The most important thing in marketing a product is to create promotional content that is creative and memorable. Marketers can also use referral groups to influence brand switching decisions by involving them in promotional activities. One of the efforts that can be done is to invite users to introduce their products to the people closest to them. This is the fastest and most effective e-WOM method in providing information about new products. In the research conducted byIrianiet al., (2021)explained that there is currently a word of mouth selling technique that can spread quickly. This sales technique can be referred to as Viral Marketing. This method is one of 
the techniques used by marketers to build a brand. The results of this study explain that viral marketing can affect consumer confidence online and can encourage consumers to make impulse purchases. Viral Marketing can be used by marketers to promote their products to the wider community. The technique used in Viral Marketing to spread information is to invite its users to share it with other users or on other social media they have. This technique is one of the techniques in the e-WOM method whose spread can be many times so that online consumer confidence in marketers can continue to increase.

\section{Conclusion}

From the discussion of respondent data analysis conducted, researchers can conclude as follows: The search for variation has a positive effect onModern Coffee Shop Consumer Brand Switching in Surabaya. e-WOM has a positive effect onModern Coffee Shop Consumer Brand Switching in Surabaya.

\section{References}

Cheng, Q., Du, R., \& Ma, Y. (2016). Factors influencing theme park visitor brand-switching behaviour as based on visitor perception. Current Issues in Tourism, 19(14), 1425-1446. https://doi.org/10.1080/13683500.2014.885497

Dahwilani, D. M. (2019). Data dan Fakta Tren Menjamurnya Kedai Kopi Kekinian di Indonesia [Blog Marketing].https://www.inews.id/travel/kuliner/data-dan-fakta-tren-menjamurnya-kedai-kopikekinian-di-indonesia

Faustine, M. (2015). The Impact of Variety Seeking, Social Status, Quality and Advertisement Towards Brand Switching in Smartphone Product (A Case Study of BlackBerry User Thas Has Ever Changed Into Another Smartphone Product in Surabaya). IBuss Management, 3(2), 142-153.

Gunawan, A., Diana, B., Muchardie, B. G., \& Sitinjak, M. F. (2016). The effect of involvement and electronic word of mouth (eWOM) on brand image and its impact on consumers brand switching of mamypoko. International Journal of Economics and Management, 10(SpecialIssue1), 19-31.

IRIANI, S. S., NUSWANTARA, D. A., KARTIKA, A. D., \& PURWOHANDOKO, P. (2021). The Impact of Government Regulations on Consumers Behaviour during the COVID-19 Pandemic: A Case Study in Indonesia. Journal of Asian Finance, Economics and Business, 8(4), 939-948. https://doi.org/10.13106/jafeb.2021.vol8.no4.0939

Justiana Astuti, H., \& Budi Santoso, S. (2020). Weakened Patient Loyalty Model at Beauty Clinics: Based on Variety Seeking Behavior, Dissatisfaction, Negative WOM and Brand Switching. SHS Web of Conferences, 86, 01032. https://doi.org/10.1051/shsconf/20208601032

Maretama, A. R., Suharyono, \& Bafadhal, A. S. (2018). Pengaruh Electronic Word Of Mouth Terhadap Brand Image Dan Brand Switching (Survei pada Mahasiswa Pengguna Operating System Android di Universitas Brawijaya). Jurnal Administrasi Bisnis (JAB), 65(1), 129-137.

Pasaribu, R., \& Sugiarto, A. (2011). Pengaruh E-WOM Terhadap Peralihan Merek Dengan Citra Merek Sebagai Variabel Mediasi. Economics and Business, 16(110), 853-862.

Pelupessy, S. J., Wardana, M., \& Suprapti, N. W. S. (2017). Peran Brand Image Dalam Memediasi 
Pengaruh Wom Terhadap Switching Intention Ke Produk Smartphone Merek Samsung Di Denpasar. Jurnal Ekonomi Dan Bisnis Universitas Udayana, 6(5), 1939-1966.

Pirdaus, A., Danial, R. D. M., \& Ramdan, A. M. (2020). ANALISIS EFEK KOMUNITAS DAN ELECTRONIC WORD OF MOUTH TERHADAP BRAND SWITCHING PRODUK XIAOMI POCOPHONE KE OPPO F9 DI RNY COMMUNICATION KOTA SUKABUMI. Journal of Management and Bussines, 2(1), 1-8. https://doi.org/10.1017/CBO9781107415324.004

Safitri, A., \& Septrizola, W. (2019). Pengaruh Dissatisfaction, Variety Seeking, Electronic Word of Mouth, dan Religiosity terhadap Brand Switching Produk Kosmetik Lain ke Kosmetik Wardah pada Mahasiswi Universitas Negeri Padang. Jurnal Kajian Manajemen Dan Wirausaha, 01(01), 26-35.

Sang, H., Xue, F., \& Zhao, J. (2018). What Happens When Satisfied Customers Need Variety? -Effects Of Purchase Decision Involvement and Product Category on Chinese Consumers' Brand-Switching Behavior. Journal of International Consumer Marketing, 30(3), 148-157. https://doi.org/10.1080/08961530.2018.1423662

Suharseno, T., Hidayat, R., \& Liana Dewi, D. (2013). Pengaruh Ketidakpuasan Konsumen Dan Karakteristik Kategori Produk Terhadap Keputusan Perpindahan Merek Dengan Kebutuhan Mencari Variasi Sebagai Variabel Moderasi. Buletin Studi Ekonomi, 18(2), 176-182.

Susanto, Y. D., \& Widyawati, N. (2016). Pengaruh Variety Seeking, Promosi, dan Citra Merek Terhadap Keputusan Perpindahan Merek. Ilmu Dan Riset Manajemen, 5, 1-15.

Thawil, A. N. (2014). Pengaruh Ketidakpuasan Pasca Konsumsi Dan Kebutuhan Mencari Variasi Terhadap Keputusan Perpindahan Merek Handphone GSM Dari Merek Blackberry Ke Samsung (Studi Pada Pengguna Handphone di Kota Manado). Jurnal Riset Bisnis Dan Manajemen, 2(4), 73-89.

Zhang, H., Takanashi, C., Gemba, K., \& Ishida, S. (2015). Empirical Research on the Influence of Negative Electronic Word-of-Mouth on Brand Switching Behavior. World Journal of Management, 6(2), 4661. https://doi.org/10.21102/wjm.2015.09.62.04.

\section{Copyrights}

Copyright for this article is retained by the author(s), with first publication rights granted to the journal.

This is an open-access article distributed under the terms and conditions of the Creative Commons Attribution license (http://creativecommons.org/licenses/by/4.0/). 